\title{
GAMMA GLUTAMYLTRANSFERASE IMPACT IN THERAPEUTIC RESPONSE OF CHRONIC HEPATITIS C: a systematic review of the literature
}

\author{
Maria de Lourdes Albuquerque de QUEIROGA ${ }^{1,2}$, Raymundo PARANÁ1, \\ José Eymard Moraes de MEDEIROS FILHO³, Giovannini Cesar A FIGUEIREDO², \\ Ananda Peixoto de ARAÚJO², Hagley Walson Soares LEITE², Itiel de Souza AQUINO² \\ and Leonardo Honório de A MELO NETO²
}

ABSTRACT - Background - The standard treatment of chronic hepatitis C is the administration of pegylated interferon $\alpha 2 \mathrm{a}$ or $\alpha 2 \mathrm{~b}$ in combination with ribavirin, but adverse effects can be observed, as well as the high cost of this therapy. Therefore, there is interest in understanding the predictors of sustained virologic response, as the gamma glutamyltransferase. Objective - To evaluate the serum levels of gamma glutamyltransferase as a predictor of response to treatment with pegylated interferon $\alpha$ and ribavirin in chronic hepatitis C. Methods - This is a systematic review of literature, conducted by consulting PUBMED, LILACS, MEDLINE, SCOPUS, Cochrane electronic databases, and active search of articles selected between January 2000 and April 2013. Results - A total of 4,785 titles were iden tified. Out of those material, following inclusion and exclusion criteria, 273 abstracts were selected, by two independent researchers. After reading those texts, the reviewers consensually included ten studies for systematization and classification, according to the criteria of the Oxford Scale. 1B studies are predominant (prospective cohort study - six studies). Rapid virologic response and early virological response were considered as estimates for the sustained virological response. The frequency of virologic response was identified in three studies and early virological response in two, with a total of 392 and 413 patients, respectively; sustained virologic response was reported in nine articles corresponding to 3,787 patients (76.5\%). Conclusion - Gamma glutamyltransferase is a predictor of sustained virologic response in the treatment of chronic hepatitis $\mathrm{C}$ with pegylated interferon $\alpha 2 \mathrm{a}$ or $\alpha 2 \mathrm{~b}$ associated with ribavirin.

HEADINGS - Gamma glutamyltransferase. Hepatitis C. Sustained virological response. Review.

\section{INTRODUCTION}

All over the world the hepatitis $\mathrm{C}$ virus (HCV) has been recognized as a major cause of chronic liver disease ${ }^{(21,28)}$, representing a public health problem.

About 170 million (3\%) of the world's population is infected with $\mathrm{HCV}^{(28,31)}$, and may develop liver disease, including cirrhosis and hepatocellular carcinoma $^{(16)}$. In Brazil, Inquérito Nacional de Hepatites Virais (National Survey of Viral Hepatitis) estimated the prevalence of $1.38 \%$ for the antibody to $\mathrm{HCV}^{(24)}$.

The pattern of chronic hepatitis $\mathrm{C}(\mathrm{CHC})$ treatment can be started with pegylated interferon (PEG-
IFN) $\alpha 2 a$ or $\alpha 2 b$ associated with ribavirin (RBV) for genotype 1, 4-6 for 48 weeks, but for genotypes 2 and 3 for 24 weeks $^{(9,23)}$.

The treatment of $\mathrm{CHC}$ is costly, and may have side effects. In addition, some factors contribute to the limited rate of sustained virologic response (SVR) of $50 \%$ to $60 \%$ as occurs in genotypes 1 and 4 .

Thus, before starting the treatment of $\mathrm{CHC}$ it is important to assess the predictive of therapeutic response to define who should be treated and when this treatment will be over ${ }^{(8)}$.

There are several therapeutic response predictor factors in $\mathrm{CHC}$, such as age at infection, gender, he-

Declared conflict of interest of all authors: none

Disclosure of funding: no funding received

${ }^{1}$ Programa de Pós-Graduação em Medicina e Saúde, Faculdade de Medicina, Universidade Federal da Bahia, Salvador, BA; ${ }^{2}$ Centro de Ciências Biológicas e da Saúde Unidade Acadêmica de Ciências Médicas, Curso de Medicina, Universidade Federal de Campina Grande, PB; ${ }^{3}$ Universidade Federal da Paraíba, João Pessoa, PB. Brasil. Correspondence: Maria de Lourdes Albuquerque de Queiroga. Rua General Newton Estilac Leal, 503. Alto Branco - CEP: $58401-750$ - Campina Grande, PB, Brasil. E-mail: qalb@uol.com.br 
patic fibrosis, genotype, viral load, virologic response, and gamma glutamyltransferase (GGT) levels ${ }^{(8)}$.

It is important to highlight other predictors of therapeutic response: serum vitamin $\mathrm{D}^{(14,25)}$; and CC (rs 12979860) Interleukin $28 \mathrm{~B}$ genotype $\mathrm{e}^{(1,22,27)}$.

The GGT enzyme catalyzes the degradation of extracellular glutathione (GSH) in the transfer of amino acids and peptides across cell membranes ${ }^{(15,19)}$, forming a "gamma-glutamyl cycle"(30).

GGT is located in hepatocytes, kidney, biliary tract, intestines, heart, spleen, pancreas, and brain ${ }^{(22)}$. However, it may be elevated in liver dysfunction, cholestasis, use of hepatotoxic drugs, as a marker of alcohol intake in pancreatitis, and association with coronary heart diseases risk ${ }^{(3,19,30)}$.

Despite many studies, there are no conclusive data on the prediction of therapeutic response of GGT. Therefore, there is interest in understanding the predictive factors of SVR and GGT.

Therefore, the aim of this systematic review $(\mathrm{SR})^{(5,17,18)}$ was to evaluate the serum levels of GGT as a predictor of treatment response in $\mathrm{CHC}$.

\section{METHODS}

\section{Search strategy}

To develop the SR we have followed the guidelines of the Centre for Reviews and Dissemination (CRD), University of York ${ }^{(6)}$.

MEDLINE, LILACS, PUBMED, SCOPUS, and Cochrane electronic databases were evaluated in search for articles published from January 2000 to December 2011. At first the gamma-glutamyltransferase descriptor (hepatitis $\mathrm{C}$ and prognostic, hepatitis $\mathrm{C}$ and fibrosis, hepatitis $\mathrm{C}$ and therapy response, predictive value, hepatitis $\mathrm{C}$ and predictive value, chronic hepatitis $\mathrm{C}$ and hepatic fibrosis, hepatitis C) then two new database searches were held, replacing the descriptor for GGT and then by gamma-glutamyltranspeptidase ${ }^{(26)}$.

Complementing the research, an active search was conducted in lists of references of the selected articles. Later, the institutional library services were used to retrieve the full articles. However, April 2013 was determined as deadline to include items in the survey. Thus, January 2000 to April 2013 was the study period.

The descriptors used in the electronic search, according to Dickersin et al., (1994) ${ }^{(10)}$, which advocates the inclusion of terms referring to the main condition, intervention and methodology.

\section{Criteria for inclusion and exclusion}

Inclusion criteria were: publications from January 2000 to April 2013; studies in English, Spanish, French and Portuguese; studies aiming to identify primary or secondary GGT as a predictor of treatment response in $\mathrm{CHC}$; articles which described the treatment of CHC PEG-IFN/RBV; articles that described histopathology; publications presenting research HCV-RNA.
Exclusion criteria were: studies describing decompensated liver disease, coinfection with hepatitis B virus (HBV) and human immunodeficiency virus (HIV), autoimmune hepatitis and drug-induced hepatitis, Wilson's disease, reported ethanol consumption $>40 \mathrm{~g} /$ day for men and $>20 \mathrm{~g} /$ day for women; publications that described the use of direct acting antiviral agents (DAAs); treatment of patients who underwent liver transplantation studies involving diagnostic tests with animal organs; reports and case series; publications in the form of theses, dissertations, proceedings of congress, abstracts and review articles.

\section{Data extraction and qualification studies}

The selected studies by reading the title were assessed by the investigator according to the criteria of inclusion, exclusion and duplicity. Then two independent reviewers assessed the material according to the criteria of selecting abstracts and full papers, and when disagreements surfaced, decisions were taken by consensus.

The studies selected for systematization were analyzed using a form that included the following variables: number of patients, age, gender, GGT; genotype; fibrosis; PEG-IFN/ $\mathrm{RBV}$, duration of treatment, HCV-RNA, rapid virologic response (RVR), early virologic response (EVR), SVR. From all the analyzed articles, the following information was recorded: title, main author, year of publication, language, journal, study site and design study.

To select the studies in a qualitative way, we used the criteria of levels of evidence and grades of recommendation proposed by the Oxford Centre for Evidence - Based Medicine, which takes into account the survey design ${ }^{(23)}$. At this scale the grade of recommendation varies from $\mathrm{A}$ to $\mathrm{D}$ with evidence level 1 to $5^{(4)}$.

\section{Data analysis}

After selecting the data from the articles, they were implemented in the software Microsoft ${ }^{\circledR}$ Office Excel 2007. A descriptive analysis of the variables from the database with percentage frequency was done.

\section{RESULTS}

\section{Characteristics of included studies}

In our research, 4,785 titles of studies were identified using the descriptors in the electronic databases, from which 3,829 were excluded for various reasons: the presentation of other treatments for CHC, studies before 2000, other hepatitis coinfection HCV/HIV, 956 remaining studies. Of these, 683 were excluded for duplicity. Therefore, 273 titles remained for abstracts reading.

After two independent researchers reviewed the abstracts by two independent, following the inclusion and exclusion criteria, 111 articles remained for retrieving, full reading and variables systematic evaluation. After the reading 103 studies were excluded, resulting in eight articles.

Using the references of these articles, two studies were selected through the active search of the references of the 
articles included in the SR. Thus, 10 studies (identified as E1 to E10) were included for classification and analysis of results.

All the 10 selected studies were published in English $(100 \%)$. It was noted that most of studies were published in $(\mathrm{n}=4 ; 40 \%)$. Germany studies are predominant $(\mathrm{n}=6 ; 60 \%)$ followed by the ones of Japan ( $n=2 ; 20 \%)$.

Most of studies were in MEDLINE database $(n=7$; $70.0 \%$ ) as shown in Figure 1.
The studies (E) were qualified according to Oxford Scale ${ }^{(4,23)}$ : Evidence 1B and Recommendation A (prospective cohort) - six studies; Evidence 2B and Recommendation B (retrospective cohort) - four studies (Table 1).

\section{Clinical, biochemical, histological and viral data}

The analyzed studies involved 5,349 patients aged between 14 and 75 years, being $55.4 \%(n=2,963)$ male.

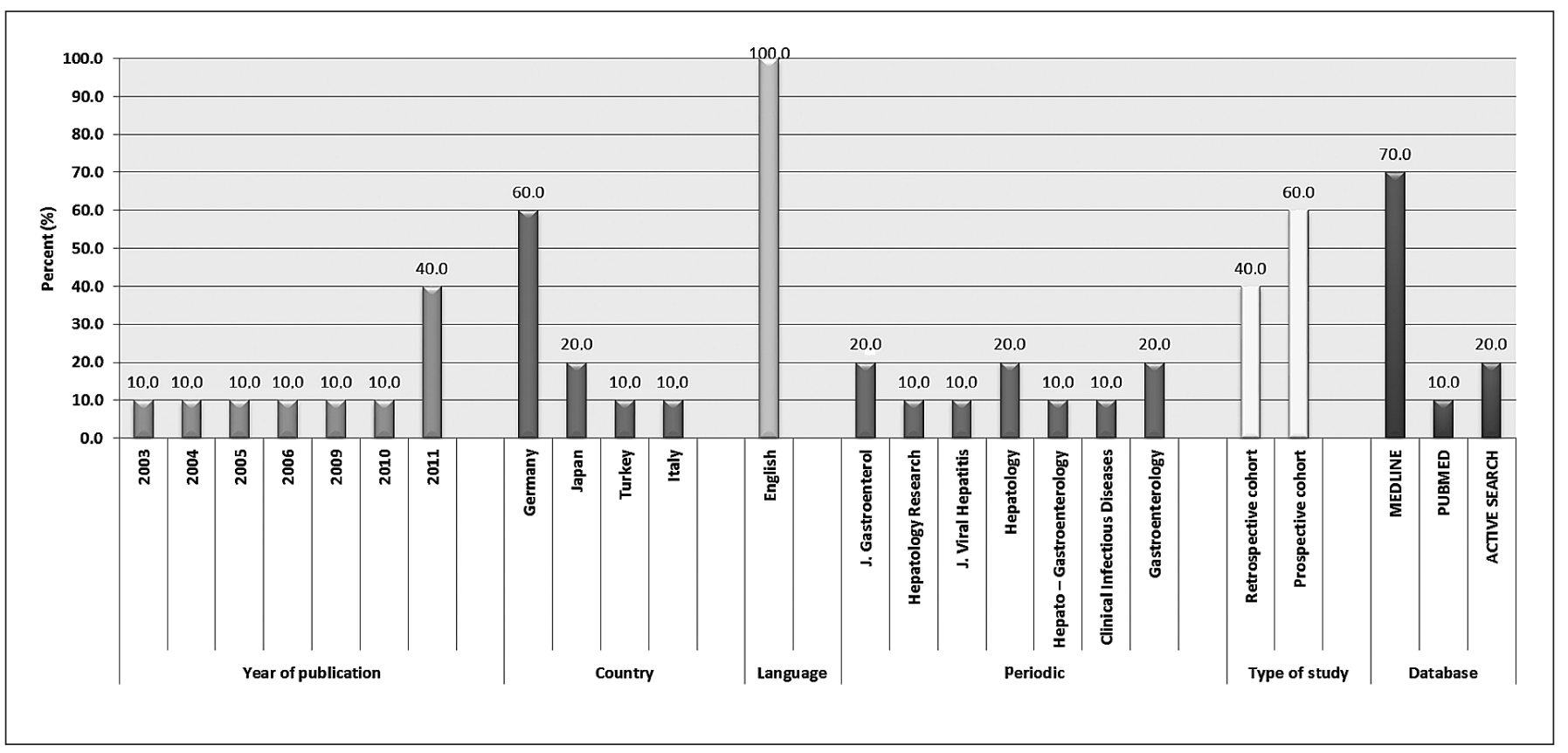

FIGURE 1. Study distribution according to the variables

TABLE 1. Characteristic of the studies in systematic review

\begin{tabular}{|c|c|c|c|c|c|c|}
\hline $\mathrm{N}^{\circ}$ Authors & Country/Year & Journal & Database & Study type/Oxford scale & $\begin{array}{c}\mathbf{N}^{\circ} \text { of } \\
\text { patients } \\
(\mathrm{n})\end{array}$ & $\begin{array}{c}\text { Gender } \\
\text { M/F }\end{array}$ \\
\hline E1 Weich et al. & Germany/2011 & J. Gastroenterol & MEDLINE & Retrospective Cohort (2B B*) & 632 & $341 / 291$ \\
\hline E2 Kurosaki et al. & Japan/2010 & Hepatology Research & MEDLINE & Prospective Cohort (1B A*) & 400 & $182 / 218$ \\
\hline E3 Mauss et al. & Germany/2011 & J. Viral Hepatitis & MEDLINE & Retrospective Cohort (2B B*) & 2,378 & $1,363 / 1,015$ \\
\hline E5 Kronenberger et al. & Germany/2004 & Hepatology & PUBMED & Prospective Cohort (1B A*) & 39 & $21 / 18$ \\
\hline E6 Kurosaki et al. & Japan/2011 & J. Gastroenterol & MEDLINE & Retrospective Cohort (2B B*) & 801 & $421 / 380$ \\
\hline E7 Çoban et al. & Turkey/2011 & Hepato - Gastroenterology & MEDLINE & Retrospective Cohort (2B B*) & 112 & $55 / 57$ \\
\hline E10 Wagner et al. & Germany/2005 & Gastroenterology & $\begin{array}{l}\text { ACTIVE } \\
\text { SEARCH }\end{array}$ & Prospective Cohort (1B A*) & 153 & $97 / 56$ \\
\hline
\end{tabular}

$\mathrm{N}^{\circ}$ : study number; E: study; (*) Oxford scale; M: male; F: female 


\section{Characteristics of therapeutic response of the SR studies}

In the 10 analyzed articles it was observed that the genotype $(\mathrm{G}) 1$ was described in eight studies $(80 \%)$, while $\mathrm{G} 2$ and G3 appeared in six. E7 was the only one without the genotype (Table 2)

The G1 was recorded isolatedly in three studies (E2, E6, E9) corresponding to the rate of SVR of 55.5\% and 53.9\% in E6 and E9 respectively. However, E2 had no information (NI) about RVS. G1, G2, and G3 together in E1, E5 and E8, the SVR rate corresponded to $58.7 \%, 59.0 \%$ and $56.3 \%$, respectively. With respect to E10, in which $\mathrm{G} 2$ and G3 were described, the SVR rate corresponded to $82.5 \%$. In this study, the End of Treatment Response (ETR) was 93\% (Table 2).

Eight items mentioned histological features, classified according to METAVIR and Knodell. In all studies HCVRNA was analyzed. The main characteristics of these studies are shown in Table 3.

With respect to the treatment protocol, PEG-IFN $\alpha 2 \mathrm{a}$ was administered in three studies, as weel as PEG-IFN $\alpha 2 b$. However, in four studies PEG-IFN $\alpha 2 \mathrm{a}$ and $\alpha 2 b$ were used. In all the studies there was the association with RBV (Table 3 ).

The study by Berg et al. (2006) ${ }^{(\mathrm{E9})}$ extended the treatment of CHC G1 from 48 to 72 weeks, forming two groups (A: $n=230 ; 48$ weeks and $B: n=225 ; 72$ weeks), with the same dose of PEG-IFN $\alpha 2 \mathrm{a} 180 \mu \mathrm{g} / 1 \mathrm{x} /$ week no association to RBV $800 \mathrm{mg} /$ day. However, the authors concluded that there was no significant difference in SVR, and that GGT levels were associated with SVR in the two groups. Because of this, it was not recommended to extend the duration of treatment in CHC G1 (Table 3).

In 2011, Çoban et al. ${ }^{(\mathrm{E} 7)}$ a retrospective cohort study was conducted to investigate predictors of SVR in patients with
CHC. The authors included 112 patients, 55 (49.1\%) males. All of them were treated with PEG-IFN $\alpha 2 b$ combined with RBV. They concluded that the serum levels of GGT, before treatment, are associated with high rates of SVR and that the GGT levels are often elevated in patients with CHC regardless of environmental factors such as alcohol consumption. Moreover, they added that GGT is a biochemical marker with low cost that may be incorporated with other predictive pretreatment factors.

RVR and EVR are described in the study Kurosaki et al. $(2010)^{(\mathrm{E} 2)}$. The authors used the decision tree model (CART - The Classification and Regression Tree), which analyzes the predictors of response to therapy with PEG-IFN and RBV. Based on these data, we observed that low levels of GGT are predictors of RVR/EVR, considering estimates for SVR (Table 3).

The various presentations of virological responses observed in the ten studies included in the SR are described in the results (Table 3).

E1 and E3 studies mentioned GGT lower than the upper limit of normal $(<\mathrm{ULN})$ and age $<40$ years as predictive factors associated with SVR GGT. Furthermore, E3 were significantly positive for the G2/G3 SVR and viral load was low. The authors suggested that treatment with PEG-IFN $\alpha 2 \mathrm{a}$ is a positive predictor of SVR, compared to PEG-IFN- $\alpha 2 b$.

In addition to the studies cited above, relevant studies that evaluate GGT as a predictor of SVR are described and summarized in Table 3.

As to the identified frequencies, related to virological response, we highlight the following: RVR in three and ETR in two studies with a total of $392(38.9 \%)$ and $413(48.3 \%)$ patients, respectively; RVE was observed in four articles; and SVR which was recorded in nine articles corresponding to $3,787(76.5 \%)$ patients.

TABLE 2. Characteristics of the genotype and therapeutic response of the studies included in SR

\begin{tabular}{|c|c|c|c|c|c|}
\hline $\mathbf{N}^{\circ}$ & Genotype & \multicolumn{4}{|c|}{ Therapeutic response (\%) } \\
\hline E2 & G1 & $60 \%$ & RVR/ETR & NI & NI \\
\hline E3 & G1-G2-G3-G4 & NI & NI & NI & $57.9 \%$ \\
\hline E5 & G1-G2-G3 & NI & NI & $80 \%$ & $59.0 \%$ \\
\hline E6 & G1 & NI & $\mathrm{NI}$ & NI & $55.5 \%$ \\
\hline E7 & SI & NI & NI & NI & $57.2 \%$ \\
\hline E10 & G2-G3 & NI & NI & $93 \%$ & $82.5 \%$ \\
\hline
\end{tabular}

$\mathrm{N}^{\circ}$ : number of study; E: study; EVR: early virologic response; RVR: rapid virologic response; ETR: end of treatment response; SVR: sustained virologic response; NI: no information; G: genotype. 
TABLE 3. Summary of GGT as a predictor of SVR in treatment with PEG-IFN/RBV studies included in RS

\begin{tabular}{|c|c|c|c|}
\hline Authors (year) & Genotype & Protocol of treatment (PEG-IFN/RBV3) & Therapy response \\
\hline \multicolumn{4}{|c|}{ E1 - The determination of GGT is the most reliable predictor of non responsiveness to interferon-alpha based therapy in HCV type-1 infection } \\
\hline $\begin{array}{l}\text { Weich et al. } \\
(2011)\end{array}$ & $\begin{array}{l}\mathrm{G} 1 \\
(\mathrm{n}=561) \\
\mathrm{G} 2 / 3 \\
(\mathrm{n}=71)\end{array}$ & $\begin{array}{l}\text { PEG IFN } \alpha 2 \mathrm{a} 180 \mu \mathrm{g} / \text { week and } \alpha 2 \mathrm{~b} 1.5 \mu \mathrm{g} / \\
\mathrm{kg} / \text { week + RBV } 800 \text { at } 1200 \mathrm{mg} / \text { day } / 24 \text { to } \\
48 \text { weeks. }\end{array}$ & $\begin{array}{l}\text { Predictive power of the GGT level to SVR - correlation with several isolated variables, age and virological load; } \\
\text { association of the binary variables, age ( } \leq 40 \text { vs }>40 \text { years), presence or absence of severe fibrosis or cirrhosis; } \\
\text { association among GGT low levels and ALT high base levels. } \\
\text { GGT < ULN: associated with best virologic response (SVR and EVR) at G1 }(P<0.0001) \text {; predictive GGT regardless } \\
\text { SVR: Multivariate logistic regression identified low GGT }(P<0.0001) \text {, high ALT }(P<0.0006) \text {, low viremia } \\
(P<0.0014) \text {, RVS independent predictors. This predictive factor may improve infection individualized theraphy; } \\
\text { HCV G1; SVR } n=371 ; 58.7 \% \text {; ETR } n=115 ; 18.2 \% ; \text { NR } n=146 ; 23.1 \% \text {. }\end{array}$ \\
\hline
\end{tabular}

E2 - A predictive model of response to peginterferon Ribavirin in chronic hepatitis $\mathrm{C}$ using classification and regression tree analysis
Kurosaki et al. G1
(2010) $\quad(\mathrm{n}=400)$
PEG-IFN $\alpha 2 \mathrm{~b} 1.5 \mu \mathrm{g} / \mathrm{kg} / \mathrm{week}+\mathrm{RBV} 60 \mathrm{mg}$
$<60 \mathrm{Kg} ; 800 \mathrm{mg} \quad 60-80 \mathrm{Kg} ; 1000 \mathrm{mg}>80$
Low GGT-RVR/EVR predictor. Performed univariate logistic regression analysis $(P<0.004)$ and multivariate logistic $\mathrm{Kg} /$ day/24 toa 48 weeks
regression $(P<0.005)$ showed significance for GGT $<40$ vs $\geq 40$; low GGT predictor of the likelihood of RVR/RVPc

CART; The Classification and Regression Tree

used to evaluate baseline predictors of response

to treatment PEG-IFN/RBV among the clinic,

biochemical, virologic and histological to define

the pre treatment algorithm and discriminate

patients who are likely responders.

Model $\mathrm{n}=269$; Validation $\mathrm{n}=131$

E3 - Estimating the likelihood of sustained virological response in chronic hepatitis C therapy

\begin{tabular}{|c|c|c|c|}
\hline \multirow{4}{*}{$\begin{array}{l}\text { Mauss et al. } \\
\text { (2011) }\end{array}$} & G1 & PEG-IFN $\alpha 2 \mathrm{a}$ ande $\alpha 2 \mathrm{~b}$ & GGT normal vs > ULN ( $>66 \mathrm{U} / \mathrm{L} /$ Male; $>35 \mathrm{U} / \mathrm{L} /$ female). GGT normal $(\mathrm{n}=1094 ; 62 \%)$ significantly higher SVR compared \\
\hline & G2 & Associated with RBV & GGT $>$ ULN $(n=822 ; 41.2 \%)$ in univariate logistic regression $(P<0.001)$. SVR significantly associated with GGT. \\
\hline & G3 & PRACTICE: Pegylated interferon and & In univariate analysis $n=1377(57.9 \%)$ achieved an SVR $(P<0.001)$. Review of G1 / $4(n=1496)$ SVR rate $46.5 \%$ \\
\hline & $\begin{array}{l}\mathrm{G} 4 \\
(\mathrm{n}=2,378)\end{array}$ & $\begin{array}{l}\text { Ribavirin: analysis of chronic hepatitis } C \\
\text { treatment in centres of excellence. }\end{array}$ & $\begin{array}{l}\mathrm{G} 2 / 3(\mathrm{n}=882) \text { rate was } 77.3 \%(P<0.001) \text {. GGT }>\mathrm{ULN} \text {, age }>40 \text { years - negative predictors of SVR in multivariate } \\
\text { analysis. Positive predictors SVR - multivariate analysis } \mathrm{G} 2, \mathrm{G} 3 \text { and low viral load; PEG-IFN } \alpha 2 \mathrm{a} \text { treatment is a }\end{array}$ \\
\hline
\end{tabular}

$(\mathrm{n}=2,378) \quad$ treatment in centres of excellence.

nalysis. Positive predictors SVR - multivariate analysis G2, G3 and low viral load; PEG-IFN $\alpha 2$ a treatment is a positive predictor of SVR compared with PEG-IFN a.2b.

E4 - Prediction of treatment outcome in patients with chronic hepatitis C: significance of baseline parameters and viral dynamics during therapy

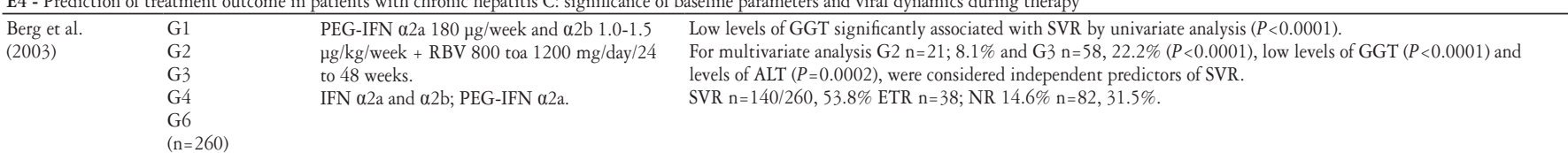

E5 - Viral kinetics during antiviral therapy in patients with chronic hepatitis $C$ and persistently normal ALT levels

E5 - Viral kinetics during antiviral therapy in patients with chronic hepatitis $\mathrm{C}$ and persistently normal ALT levels
$\begin{array}{llll}\text { Kronenberger et al. G1 } & \text { PEG-IFN } \alpha 2 \mathrm{a} 180 \mu \mathrm{g} / \mathrm{x} / \mathrm{week}+\mathrm{RBV} 800- & \text { Normal GGT levels: associated with greater loss of infected cells before treatment }(P=0.005) \text {. } \\ (2004) & \text { G2 } & 1200 \mathrm{mg} / 24 \text { to } 48 \text { weeks } & \text { GGT high: association with reduced efficacy of blocking virus production and less loss of the }\end{array}$

G3 $\quad$ GGT: $52 \mathrm{UI} / \mathrm{L} / \mathrm{masc}$; 33UI/L/fem.

$(\mathrm{n}=39)$

levels $(P=0.02)$

GGT levels were significantly lower in SVR compared to NR 24 weeks after completion of therapy $(P=0.002)$

E6 - Pretreatment prediction of response to peginterferon plus Ribavirin therapy in genotype 1 chronic hepatitis $\mathrm{C}$ using data mining analysis

Kurosaki et al. G1 PEG-IFN $\alpha 2 \mathrm{~b} 1.5 \mu \mathrm{g} / \mathrm{kg} / \mathrm{SC} / \mathrm{week} / \mathrm{RBV} 600 \quad$ By multivariate analysis GGT is associated with SVR $P=0.005$.

(2011) $(\mathrm{n}=800) \quad \mathrm{mg}-60 \mathrm{~kg}, 800 \mathrm{mg} 60-80 \mathrm{~kg}, 1000 \mathrm{mg}>80 \mathrm{~kg} /$ Factors associated with SVR, GGT < 40IU/L associated with SVR

day/24 to 48 weeks. $\quad$ GGT independently associated with SVR.

Decision tree model: $n=506$; Validation $n=294$. Pac. with low levels of GGT higher probability of SVR $(57 \%$ vs $34 \%)$ SVR rate ranging from $22 \%$ to $77 \%$. Developed to predict RVS at PEG-IFN and RBV.

E7 - Gamma-glutamyltranspeptidase in predicting sustained virological response in individuals with chronic hepatitis C

Çoban et al. SI SEG-IFN $\alpha 2 \mathrm{~b} 1.5 \mu \mathrm{g} / \mathrm{kg} /$ week RBV 800 to $\quad$ Low levels of GGT before treatment: associated with high rates of SVR

(2011) $\quad(\mathrm{n}=112) \quad 1200 \mathrm{mg} /$ day, $(<65 \mathrm{~kg}, 800 \mathrm{mg} /$ day; $65-85 \mathrm{~kg}$, Normal GGT predictor of SVR.

$1000 \mathrm{mg} /$ day; $>85 \mathrm{~kg} 1200 \mathrm{mg} /$ day). During $\quad$ SVR: $\mathrm{n}=64 / 112 ; 57.2 \%$ (combination therapy).
Factors associated with SVR: lower in patients with

12 months.

$70.4 \%)$.

SVR $>$ GGT Normal Group $(\mathrm{n}=38 / 54,70.4 \%)$ than in Group GGT $>50 \mathrm{IU} / \mathrm{mL}(\mathrm{n}=26 / 58,44.8 \%) P=0.0098$ and

GGT $>100(\mathrm{n}=9 / 26,34.6 \%) P=0.0018$ - Analysis of multivariate regression.

E8 - Correlates and prognostic value of the first-phase hepatitis $C$ virus RNA kinetics during treatment

Durant-Mangoni G1n=61 PEG-IFN $\alpha 2 \mathrm{a} 180 \mu \mathrm{g} /$ week or PEG-IFN $\quad$ GGT levels $(P<0.001)$ and RVR $(P<0.001)$ are among the factors significantly associated with SVR by univariate

et al. $\quad \mathrm{G} 2 \mathrm{n}=44$

alfa-2b $1.5 \mu \mathrm{g} / \mathrm{kg} / \mathrm{week}$ analysis.

Combined RB $800 \mathrm{mg} /$ day ( $400 \mathrm{mg}$ twice

day) for $\mathrm{G} 2$ or $\mathrm{G} 3 ; 1000$ or $1200 \mathrm{mg} /$ day for
$\mathrm{G} 1<75$ ou $\geq 75 \mathrm{~kg}$, respectively. G1 48 week.

day) for $\mathrm{G} 2$ or $\mathrm{G} 3 ; 1000$ or $1200 \mathrm{mg} /$ day for
$\mathrm{G} 1<75$ ou $\geq 75 \mathrm{~kg}$, respectively. G1 48 week

GGT: an independent predictor of SVR in the first phase of viral response through multivariate regression analysis

SVR: $n=67 / 119 ; 56.3 \%$ NR: $n=29 / 119$; Relapse $24.4 \%: n=23 ; 19.3 \%$. and $\mathrm{G} 2 / \mathrm{G} 324$ weeks

E9 - Extended tratment duration for hepatitis C virus type 1: comparing 48 versus 72 weeks of peginterferon - alfa -2a plus Ribavirin

Berg et al. G1 PEG-IFN $\alpha 2 \mathrm{a} 180 \mu \mathrm{g} / 1 \mathrm{x} /$ week + RBV $800 \mathrm{mg} \quad$ Groups A and B: GGT levels identified as independent predictors through multivariate regression analysis $(P<0.001)$ (2006) $\quad(\mathrm{n}=455) \quad \mathrm{VO} /$ day

Group A ( $\mathrm{n}=230)$ : 48 week; Group B ( $\mathrm{n}=225)$ : ETF and SVR in group A and group B were $71 \%$ vs $63 \%$ and $53 \%$ vs $54 \%$ respectively, without significant 72 weeks.

difference.

Extend the duration of treatment is not recommended in HCV G1 infection and should be reserved only for patients with slow virologic response, defined as HCV-RNA positive at week 12 but negative at week 24 .

E10 - Peginterferon-alfa-2a (40KD) and Ribavirin for 16 or 24 Weeks in patients with genotype 2 or 3 chronic hepatitis C

\begin{tabular}{lll}
\hline Wagner et al. & $\mathrm{G} 2$ & PEG-IFN $\alpha 2 \mathrm{a} 180 \mu \mathrm{gg} / \mathrm{x} / \mathrm{week} / \mathrm{SC}+\mathrm{RBV}$ \\
$(2005)$ & $(\mathrm{n}=39 ; 26 \%)$ & $800-1200 \mathrm{mg} / \mathrm{day} / \mathrm{VO} . \mathrm{RBV}:$ \\
& $\mathrm{G} 3$ & $(\leq 65 \mathrm{~kg}: 800 \mathrm{mg} ; 65-85 \mathrm{~kg}: 1000 \mathrm{mg} ;>85 \mathrm{~kg}:$ \\
& $(\mathrm{n}=113 ; 74 \%)$ & $1200 \mathrm{mg})$. \\
& $\mathrm{G} 2 / 3$ & \\
& $(\mathrm{n}=1 ;<1 \%)$ & \\
& $(\mathrm{n}=153)$ & \\
\hline
\end{tabular}

RVR (HCV RNA $<600 \mathrm{IU} / \mathrm{mL}$ at week 4 ):

Group A: $\mathrm{n}=71 ; 16$ weeks; ETR: 94\%; SVR: $82 \%$.

Group B: $\mathrm{n}=71 ; 24$ weeks; ETR: $85 \%$; SVR: $80 \%$.

HCV RNA $\geq 600 \mathrm{IU} / \mathrm{mL}$ at week 4 :

Group C: $\mathrm{n}=11 / 153 ; 7 \%$; $24 \%$ weeks; ETR: $73 \%$; SVR: $36 \%$.

Low GGT level: independent predictor of SVR by multivariate regression analysis.

G2/G3 (low viral load): RVR - Treatment / 16 weeks; G3 (high viral load): Treatment. longer may be required.

PEG-IFN: pegylated interferon, RBV: Ribavirin; Nr: number of study; E: studies; NI: no information; NR: not responder; EVR: early virologic response; RVR: rapid virologic response;

ETR: end of treatment response; SVR: sustained virologicaql response; ALT: alanine transaminase 


\section{DISCUSSION}

In this SR it is observed that most of the studies described the importance of GGT as a predictor of SVR. This information is described in the results, conclusion and also summaries. On the other hand, in some studies (E5, E8, E9 and E10), the viral kinetics and the extended or reduced treatment time CHC PEG- $\alpha$-IFN/RBV treatment regimen are highlighted. However, it is observed that GGT was described as a predictor of SVR when analyzing in detail the results of these articles. In several studies, normal or low serum levels of GGT, before treatment, are associated with high rates of SVR. Citing as an example the E1, E3, E4, E7 studies.

Çoban et al. ${ }^{(\mathrm{E} 7)}$, and Weich et al..$^{(\mathrm{E} 1)}$, demonstrated that serum GGT may be elevated in CHC, cholestasis, use of hepatotoxic drugs and as a marker of alcohol intake, confirming what some previous studies describe ${ }^{(3,19,30)}$.

Another important parameter was observed by Berg et al. ${ }^{(\mathrm{A})}$, who evaluated the therapeutic response using PEGIFN $\alpha 2 \mathrm{a}$ or PEG-IFN $\alpha 2 \mathrm{~b}$ and RBV but also included IFN $\alpha$ in the study. Despite the evidence have shown low levels of GGT as an independent predictor of SVR, with these data, it may be considered a bias, since the analysis of the results PEG-IFN and conventional IFN were evaluated together.

The likelihood of SVR is an important factor in the decision to initiate and continue therapy of CHC. Mauss et al.(E3), with the goal of identifying predictors of SVR in patients treated with PEG-IFN ( $\alpha 2 a$ or $\alpha 2 b$ ) and RBV reported high levels of GGT as a negative predictor, however, treatment with PEG-IFN $\alpha 2$ a was considered positive predictor compared to PEG-IFN $\alpha 2 b$.

In a recent study, Garcia et al. ${ }^{(13)}$, to compare the side effects of treatment of CHC with PEG-IFN ( $\alpha 2 a$ or $\alpha 2 b$ ) and RBV, observed that treatment with PEG-IFN $\alpha 2 b$ cause more fever and weight loss as side effects when compared to PEG-IFN $\alpha 2$ a RBV associated with a statistically significant relationship $(P<0.05)$.

Berg et al. ${ }^{(\mathrm{E} 9)}$ prolonged the $\mathrm{G} 1 \mathrm{CHC}$ treatment with PEG-IFN $\alpha 2 \mathrm{a} / \mathrm{RBV}$ from 48 to 72 weeks, but concluded that GGT levels were associated with SVR in both groups, and therefore, it was not recommended to extend the duration of treatment.

On the other hand, in a previous study Von Wagner et al. (E10) 153 evaluated patients chronically infected with HCV -2 and HCV- 3 with levels of HCV- RNA pretreatment $\leq 800,000 \mathrm{IU} / \mathrm{mL}$, which have achieved RVR and can be treated for only 16 weeks with PEG-IFN $\alpha 2 \mathrm{a}$ and RBV without compromising the chances of SVR. However, these authors suggest that in patients with HCV - 3 high viral load, a longer treatment may be necessary ${ }^{(\mathrm{E} 10)}$.

In a previous study of patients with $\mathrm{CHC} \mathrm{G} 2$ or $\mathrm{G} 3$ it has been determined that treatment should be PEG-IFN $\alpha /$ RBV for 24 weeks $^{(32)}$ without interfering with the SVR.

The genome of HCV exhibits significant genetic variability, referred to as quasispecies. This phenomenon has been associated with the development of chronic infection, pathogenicity and resistance to antiviral drugg ${ }^{(12)}$. Aiming to elevate SVR in treatment PEG-IFN/RBV, GGT has been described as a predictor of SVR in therapeutic monitoring of patients with PEG-IFN/RBV with $\mathrm{CHC}^{(8)}$. Another function of this enzyme as a marker of liver fibrosis was reported in the study by Arain et al., 2011 ${ }^{(2)}$.

Recent publications have described genetic parameters, represented by interleukin 28B (IL28B) Polymorphism of single nucleotide (Single Nucleotide Polimorfhism - SNP) rs $12979860 \mathrm{DC}$ as a predictor of SVR in the treatment of CHC with PEG-IFN/RBV $(7,11,27)$.

Other associations of GGT as a predictor of virological response were reported in the study by Everhart and Wright $(2013)^{(11)}$. From this study, it is important to note the authors' conclusion that described the GGT in low serum as an independent predictor of SVR and clinical outcomes in patients with advanced liver disease due to $\mathrm{HCV}$.

Interestingly, as noted by Berg et al. ${ }^{(\mathrm{E})}$, this effect of GGT as a predictor of response to treatment has never been followed in large trials of antiviral treatment, and factors involved in the high prevalence of increased levels of GGT in $\mathrm{CHC}$ remain unclear.

In the study by Garcia - Martin et al. ${ }^{(14)}$, whose objective was to evaluate the polymorphism (Single Nucleotide Polimorphim - SNP) of the gene of vitamin D (Vitamin D Receptor - VDR) as a biomarker of response to treatment of PEG-IFN/RBV with CHC, 238 patients were evaluated. Based on the results, the authors concluded that the VDR gene polymorphisms are associated with the therapeutic response of $\mathrm{CHC}$ and can be used as a complementary biomarker response in association with demographic, virological, biochemical and genetic characteristics variables.

GGT is a simple biochemical marker available in outpatient clinics at a low cost, once its usefulness as a predictive is better understood, it may be incorporated into the routine assessment of response to therapy in conjunction with other predictors $^{(29)}$.

The treatment to cure $\mathrm{CHC}$ is a real public health benefit, mainly by reducing the risk of complications. With the access to modern therapies, one can obtain cure for the disease and the effectiveness of the treatment significantly increases the survival of infected patients ${ }^{(20)}$.

Study results allow us to conclude that low levels of GGT, G2 and G3, low viral load and high alanine transaminase (ALT) levels are independent predictors of SVR for the treatment of $\mathrm{CHC}$ with PEG-INF $\alpha / \mathrm{RBV}$. Furthermore, it is suggested that GGT may be incorporated into tests for the treatment of CHC along with other predictors of SVR, highlighting the IL 28B and vitamin D.

Predictors of treatment response, new antiviral drugs such as protease inhibitors (Telaprevir and Boceprevir), and the constant search for new discoveries in the treatment and cure of $\mathrm{CHC}$ can change the natural history of the disease.

\section{Limitations of the studies included in SR}

Among the limitations found in the evaluated studies, relevant are the following: the information of variables, which include numeric, continuous and reviews data, 
hindering the drafting tables and analysis of results; low number of papers included in this review; not include publications that dealt with CHC DAAS, specifically the association Protease Inibitor (PI) with PEG-IFN/RBV. Despite the possibility of a reduction in the number of articles occurs, the PI were not included because it refers only to genotype 1 ; studies describing alcohol intake $>40 \mathrm{~g}$ for men and $>20 \mathrm{~g}$ for women because it is a confounding variable, and were also excluded, since alcohol can have an inhibitory effect on the response to antiviral therapy in patients infected with $\mathrm{HCV}$ and, on the other hand, the alcohol consumption may increase levels of GGT.

\section{CONCLUSION}

Based on the studies evaluated in this systematic review, we conclude that low or normal levels of GGT may be considered a positive independent predictor of SVR in the PEGIFN $\alpha 2 \mathrm{a}$ or PEG-IFN $\alpha 2 \mathrm{~b}$ and RBV combination therapy.

\section{Authors' contributions}

Queiroga MLA: designed and conducted a systematic search for articles, structuring method, literature review, data collection, statistical analysis, drafting and review of the manuscript and coordination of the working group. Paraná R: guidance in the writing of the manuscript, structuring method, literature review and drafting and reviewing the manuscript. Medeiros Filho JEM: guidance in the writing of the manuscript, structuring of the methodology and performed a systematic search for articles. Figueiredo GCA: structuring of the methodology, statistical analysis; performed a systematic search for articles and reviewing the manuscript. Araújo AP: literature review, performed a systematic search for articles and data collection. Leite HWS: literature review, performed a systematic search for articles and data collection. Aquino IS: literature review, performed a systematic search for articles and data collection. Melo Neto LHA: literature review, performed a systematic search for articles and data collection.

Queiroga MLA, Paraná R, Medeiros Filho JEM, Figueiredo GCA, Araújo AP, Leite HWS, Aquino IS, Melo Neto LHA. Impacto da gama glutamiltransferase na resposta terapêutica da hepatite C crônica: revisão sistemática da literatura. Arq Gastroenterol. 2015,52(3):239-46.

RESUMO - Contexto - $\mathrm{O}$ tratamento padrão da hepatite $\mathrm{C}$ crônica consiste na administração de interferon peguilado $\alpha 2 \mathrm{a}$ ou $\alpha 2 \mathrm{~b}$ associado à ribavirina. Contudo, podem ser observados efeitos adversos além do alto custo desta terapêutica. Por isso há interesse no conhecimento dos fatores preditivos de resposta virológica sustentada como a gama glutamiltransferase. Objetivo - Avaliar os níveis séricos da gama glutamiltransferase como fator preditivo de resposta terapêutica com interferon peguilado $\alpha$ e ribavirina na hepatite C crônica. Métodos - Trata-se de uma revisão sistemática da literatura, conduzida através de consulta às bases eletrônicas de dados PUBMED, LILACS, MEDLINE, SCOPUS e COCHRANE, e busca ativa das referências dos artigos selecionados, no período de janeiro de 2000 a abril de 2013. Resultados - Foram identificados 4.785 títulos. Destes, seguindo os critérios de inclusão e exclusão, foram selecionados 273 resumos para a leitura por dois pesquisadores independentes. Após a leitura dos artigos, na íntegra e em consenso, os revisores incluíram dez estudos, para sistematização e qualificação, segundo os critérios da Escala de Oxford. Predominaram os estudos 1B A (Coorte prospectivo - seis estudos), publicações da Alemanha. A frequência de resposta virológica rápida foi identificada em três estudos e resposta virológica precoce em dois estudos, com um total de 392 e 413 pacientes respectivamente; a resposta virológica sustentada foi registrada em nove artigos correspondendo a 3.787 pacientes (76,5\%). Conclusão - O nível sérico da gama glutamiltransferase é um fator preditivo de resposta virológica sustentada no tratamento da hepatite $\mathrm{C}$ crônica com interferon peguilado $\alpha 2 \mathrm{a}$ ou $\alpha 2 \mathrm{~b}$ associado à ribavirina.

DESCRITORES - Gama glutamiltransferase. Hepatite C. Resposta virológica sustentada. Revisão.

\section{SYSTEMATIZED ARTICLES}

\section{Study (E)}

E1. Weich V, Herrmann E, Chung TL, Sarrazin C, Hinrichsen H, Buggisch P, Gerlach T, Klinker H, Spengler U, Bergk A, Zeuzem S, Berg T. The determination of GGT is the most reliable predictor of nonresponsiveness to interferon-alpha based therapy in HCV type-1 infection. J Gastroenterol. 2011;46(12):1427-36.

E2. Kurosaki M, Matsunaga K, Hirayama I, Tanaka T, Sato M, Yasui Y, Tamaki N, Hosokawa T, Ueda K, Tsuchiya K, Nakanishi H, Ikeda H, Itakura J, Takahashi Y, Asahina Y, Higaki M, Enomoto N, Izumi N. A predictive model of response to peginterferon ribavirin in chronic hepatitis $\mathrm{C}$ using classification and regression tree analysis. Hepatol Res. 2010;40(4):251-60.

E3. Mauss S, Hueppe D, John C, Goelz J, Heyne R, Moeller B, Link R, Teuber G, Herrmann A, Spelter M, Wollschlaeger S, Baumgarten A, Simon KG, Dikopoulos $\mathrm{N}$, Witthoeft T. Estimating the likelihood of sustained virological response in chronic hepatitis C therapy. J Viral Hepat. 2011;18(4):e81-90.

E4. Berg T, Sarrazin C, Herrmann E, Hinrichsen H, Gerlach T, Zachoval R, Wiedenmann B, Hopf U, Zeuzem S. Prediction of treatment outcome in patients with chronic hepatitis $\mathrm{C}$ : significance of baseline parameters and viral dynamics during therapy. Hepatology. 2003;37(3):600-9.
E5. Kronenberger B, Herrmann E, Micol F, Von Wagner M, Zeuzem S. Viral kinetics during antiviral therapy in patients with chronic hepatitis $\mathrm{C}$ and persistently normal ALT levels. Hepatology. 2004;40(6):1442-9.

E6. Kurosaki M, Sakamoto N, Iwasaki M, Sakamoto M, Suzuki Y, Hiramatsu N, Sugauchi F, Yatsuhashi H, Izumi N. Pretreatment prediction of response to peginterferon plus ribavirin therapy in genotype 1 chronic hepatitis $\mathrm{C}$ using data mining analysis. J Gastroenterol. 2011;46(3):401-9.

E7. Çoban S, Idilman R, Erden E, Tüzün A. Gamma-glutamyltranspeptidase in predicting sustained virological response in individuals with chronic hepatitis $C$. Hepatogastroenterology. 2011;58(109):1301-6.

E8 Durante-Mangoni E, Zampino R, Portella G, Adinolfi LE, Utili R, Ruggiero G. Correlates and prognostic value of the first-phase hepatitis $C$ virus RNA kinetics during treatment. Clin Infect Dis. 2009; 49(4):498-506.

E9. Berg T, Von Wagner M, Nasser S, Sarrazin C, Heintges T, Gerlach T, Buggisch P, Goeser T, Rasenack J, Pape GR, Schmidt WE, Kallinowski B, Klinker H, Spengler U, Martus P, Alshuth U, and Zeuzem S. Extended Tratment Duration for Hepatitis C Virus Type 1: Comparing 48 Versus 72 Weeks of PeginterferonAlfa -2a Plus Ribavirin. Gastroenterology. 2006;130(4):1086-97.

E10. von Wagner M, Huber M, Berg T, Hinrichsen H, Rasenack J, Heintges T, Bergk A, Bernsmeier C, Häussinger D, Herrmann E, and Zeuzem S. Peginterferon-alfa-2a (40KD) and ribavirin for 16 or 24 weeks in patients with genotype 2 or 3 chronic hepatitis C. Gastroenterology. 2005;129(2):522-7. 


\section{REFERENCES}

1. Amanzada A, Goralczyk AD, Schneider S, Moriconi F, Lindhorst A, Mihm S, Van Thiel DH, Ramadori G. High Predictability of a Sustained Virological Response $(87 \%)$ in Chronic Hepatitis C Virus Genotype 1 Infection Treatment by Combined IL28B Genotype Analysis and $\gamma$-Glutamyltransferase/Alanine Aminotransferase Ratio: A Retrospective Single-Center Study. Digestion. 2012;86(3):218-27.

2. Arain SA, Jamal Q, Omair A. Liverscore is predictive of both liver fibrosis and activity in chronic hepatitis C. World J Gastroenterol. 2011;17(41):4607-13.

3. Araújo LMB, Lima DS, Daltro C, Cotrim HP. Enzimas hepáticas em mulheres obesas: relação com classe de obesidade e tolerância à glicose. GED. 2004;23: 260-64.

4. Associação Médica Brasileira; Conselho Federal de Medicina. Projeto diretrizes Texto introdutório. [Access 2013 April 12]. Available from: <http://www.projetodiretrizes.org.br/projeto_diretrizes/texto_introdutorio.pdf $>$.

5. Atallah AN, Castro AA. Revisão Sistemática da Literatura e Metanálise: a melhor forma de evidência para tomada de decisão em saúde e a maneira mais rápida de atualização terapêutica. Diagnóstico e Tratamento. 1997;2(2):12-5.

6. Centre for Reviews and Dissemination, University of York, 2008. Systematic Reviews. CRD's guidance for undertaking reviews in health care. NHS, 2001.

7. Chen Y, Xu HX, Wang LJ, Liu XX, Mahato RI, Zhao YR. Meta-analysis: IL28B polymorphisms predict sustained viral response in $\mathrm{HCV}$ patients treated with pegylated interferon- $\alpha$ and Ribavirin. Aliment Pharmacol Ther. 2012;36: 91-103.

8. Coelho HSM, Villela-Nogueira CA. Predictors of response to chronic hepatitis C treatment. Ann Hepatol. 2010;9(Suppl1):54-60.

9. Craxi A, Pawlotsky JM, Wedemeyer H, Bjoro K, Flisiak R, Forns X, et al. EASL. Clinical Practice Guidelines: Management of hepatitis $\mathrm{C}$ vírus infection. J. Hepatol. 2011;55(2):245-64.

10. Dickersin K, Scherer R, Lefebvre C. Systematic Reviews Identifying Relevant Studies for Systematic Reviews. BMJ.1994;309(6964):1286-91.

11. Everhart JE, Wright EC. Association of c-Glutamyl Transferase (GGT) Activity With Treatment and Clinical Outcomes in Chronic Hepatitis C (HCV). Hepatology. 2013;57(5):1725-33.

12. Farci P, Purcell R. Clinical Significance of Hepatitis C Virus genotypes and Quasispecies. Semin Liver Dis. 2000;20(1):103-26.

13. Garcia TJ, Lara PHS, Morimoto TP, Higasiaraguti M, Perejão AM, Ayub MA. Efeitos colaterais do tratamento da hepatite $\mathrm{C}$ no polo aplicador do ABC. Rev Assoc Med Bras. 2012;58:543-49.

14. García-Martın E, Agúndez JAG, Maestro ML, Suárez A, Vidaurreta M, Martinez C, et al. Influence of Vitamin D-related Gene Polymorphisms (CYP27B and VDR) on the Response to Interferon/Ribavirin Therapy in Chronic Hepatitis C. PLoS One. 2013;8(9):e74764.

15. Goldberg DM. Strutural, function, and clinical aspects of gamma-glutamyltransferase. CRC Crit Rev Clin Lab Sci.1980;12(1):1-58.

16. Hanafiah KM, Groeger J, Flaxman AD, Wiersma ST. Global epidemiology of hepatitis C Virus Infection: new estimates of age-specific antibody to HCV seroprevalence. Hepatology. 2013;57(4):1333-42.
17. Higgins JPT, Green S. Cochrane Handbook for Systematic Reviews of Interventions Version 5.1.0. The Cochrane Collaboration, 2011.

18. Jadad AR, Moore RA, Carroll D, Jenkinson C, Reynolds DJN, Gavaghan DJ, McQuay HJ. Assessing the Quality of Reports of Randomized Clinical Trials: Is Blinding Necessary? Control Clin Trials.1996;17(1):1-12.

19. Lopes HJJ. Enzimas no laboratório clínico - Afecções diagnósticas. Gold Analisa Diagnóstica Ltda. Belo Horizonte-MG, 1998;1-28.

20. Marinho RT, Barreira DP. Hepatitis C, stigma and cure. World J Gastroenterol. 2013;19(40):6703-9.

21. Martins T, Narciso-Schiavon JL, Schiavon LL. Epidemiologia da infecção pelo virus da hepatite C. Revista Assoc Med Bras. 2011;57:107-12.

22. McCarty JJ, Li JH, Thompson A, Suchindran S, Lao XQ, Patel K, Tillmann HL, Muir AJ, McHutchison JG. Replicated association between an IL28B gene varian and a sustained response to pegylated interferon and Ribavirin. Gastroenterology. 2010;138(7):2307-14.

23. Ministério da Saúde. Secretária de Vigilância em Saúde. Departamentos de DST, Aids e Hepatites Virais. Protocolo Clínico e Diretrizes Terapêuticas para Hepatite Viral C e Coinfecções. Brasília - DF, 2011.

24. Pereira LMMB, Martelli CMT, Moreira RC, Merchan-Hamman E, Stein AT, Cardoso RMA, et al. Prevalence and risk factors of Hepatitis C virus infection in Brazil, 2005 through 2009: a cross-sectional study. BMC Infect Dis. 2013;13:60. 2013.

25. Petta S, Camma C, Scazzone C, Tripodo C, Di Marco V, Bono A, et al. Low vitamin $\mathrm{D}$ serum level is related to severe fibrosis and low responsiveness to interferon-based therapy in genotype 1 chronic hepatitis C. Hepatology. 2010;51(4) 1158-67.

26. Rodrigues HGC. Uso de marcadores moleculares em amostras obtidas de punção aspirativa pré-operatória de tireóide: análise secundária de dados. Tese de doutorado - Universidade Federal da Bahia, Salvador, 2012;82p.

27. Saludes V, Bascuñana E, Jordana-Lluch E, Casanovas S, Ardèvol M, Soler E, Planas R, Ausina V, Martro' E. Relevance of Baseline Viral Genetic Heterogeneity and Host Factors for Treatment Outcome Prediction in Hepatitis C Virus 1b-Infected Patients. PLoS One. 2013;8(8): e72600.

28. Shepard CW, Finelli L, Alter MJ. Global epidemiology of hepatitis C virus infection. Lancet Infect Dis. 2005;5(9):558-67.

29. Villela-Nogueira CA, Perez RM, Soares JAS, Coelho HSM. Gamma-glutamy transferase (GGT) as an independent predictive factor of sustained virologic response in patients with hepatitis $\mathrm{C}$ Treated with interferon-alpha and Ribavirin. J Clin Gastroenterol. 2005;39(8):728-30.

30. Whitfield JB. Gamma glutamyl transferase. Crit Rev Clin Lab Sci. 2001;38(4): 263-355.

31. World Health Organization (WHO). Hepatitis C-2002. Geneva: WHO, 2003 [Accessed 2012 June 27]. Available from: <http://www.who.int/csr/disease/hepatitis/Hepc.pdf>.

32. Zéuzem S, Feinman SV, Rasenack J, Heathcote J, Lai MY, Gane E, O' Grady J, Heichen J, Diago M, Lin A, Hoffman J, Brunda MJ. Peginterferon alfa-2a in patients with chronic hepatitis C. N Engl J Med.2000;343(23):1666-72. 